\title{
Reduced Levels of Serum 25-Hydroxyvitamin D in Alopecia Areata: A Systematic Review and Meta-analysis
}

\author{
Felix Paolo J. Lizarondo, ${ }^{1}$ Patricia A. Nacianceno ${ }^{1}$ and Claudine Yap-Silva ${ }^{2}$ \\ ${ }^{1}$ Section of Dermatology, Department of Medicine, Philippine General Hospital, University of the Philippines Manila \\ ${ }^{2}$ Section of Dermatology, Department of Medicine, College of Medicine and Philippine General Hospital, University of the Philippines Manila
}

\begin{abstract}
Background. Alopecia areata is postulated to be an autoimmune disease of which vitamin D may play a role being found in the immune system and hair.
\end{abstract}

Objective. To determine the association between serum 25 -hydroxyvitamin $\mathrm{D}$ levels in patients with alopecia areata compared with healthy controls.

Methods. Observational studies on association of vitamin D levels on alopecia areata compared to healthy controls were obtained from all published articles until July 2018 on MEDLINE, Cochrane Library, TRIP, HERDIN, and Google. Review Manager 5.3 was used for the meta-analysis.

Results. The search strategy yielded 13 qualified articles for the full-length review and 11 studies, containing 916 patients, were included in the meta-analysis using the pooled random effects model. The pooled mean difference of the serum 25-hydroxyvitamin D levels between alopecia areata patients and healthy controls was $-9.55(95 \%$ $\mathrm{Cl},-10.51$ to -8.59$)$ with heterogeneity $\left(\mathrm{I}^{2}=85 \%\right)$.

Conclusion. In conclusion, there were reduced levels of serum 25-hydroxyvitamin D levels in alopecia areata compared to healthy controls and vitamin D deficiency was more prevalent in alopecia areata compared to healthy controls. There was also a trend of lower vitamin D levels in the more severe forms of alopecia.

Key Words: alopecia areata, vitamin D, 25-hydroxyvitamin D

E-poster presented at the $39^{\text {th }}$ Annual Convention of the Philippine Dermatological Society, November 3-5 2016, EDSA Shangri-La, Mandaluyong City, Philippines.

Corresponding author: Felix Paolo J. Lizarondo, MD

Section of Dermatology

Department of Medicine

College of Medicine

Philippine General Hospital

University of the Philippines Manila

Taft Avenue, Manila 1000, Philippines

Telephone: +632 5548400 local 5105/5106

Email: fjlizarondo@up.edu.ph

\section{INTRODUCTION}

\section{Description of the condition}

Alopecia areata is a non-cicatricial alopecia that occurs worldwide in all populations, comprising of 0.7 to $3.8 \%$ of dermatology clinic consults. ${ }^{1}$ This nonscarring alopecia is largely postulated to be an organ-specific autoimmune disease affecting the hair follicles. ${ }^{2}$ The main mechanisms by which the hair follicle is targeted by the immune system are breakdown of the hair follicle immune privilege and the production of autoantigens. ${ }^{3}$ Histopathologically, this is seen as characteristic finding of lymphocytic infiltrates in the peribulbar area of anagen hair, typically seen in the acute stage of the disease. ${ }^{4}$ Clinically, alopecia areata manifests as solitary or multiple non-scarring round or oval hairless patches of which the border commonly having exclamation point/tapering hairs have a broader distal end relative to the proximal end. ${ }^{2}$ Alopecia areata can be classified as patchy, alopecia totalis, and alopecia universalis wherein in there is 
partial loss of hair in the scalp, 100\% involvement of scalp hair, and 100\% involvement of both scalp and body hair, respectively. ${ }^{1}$ Other variants which are relatively uncommon include diffuse thinning all over the scalp, reticular hairless patches, Ophiasis, Ophiasis inversus, and band-like hair loss in the parieto-temporo-occipital or fronto-parietotemporal area. ${ }^{1}$

\section{Vitamin $\mathrm{D}$ and its possible role in alopecia areata}

Vitamin $\mathrm{D}$ is a fat-soluble hormone that functions mainly in calcium homeostasis, stimulating its intestinal and renal absorption and in bone homeostasis, interacting with osteoclasts for bone resorption to maintain adequate serum levels of calcium. ${ }^{5}$ This hormone has two main sources: the skin and diet. With sun exposure, specifically the UVB spectrum (mean of 295-305nm), the preformed 7-dehydrocholesterol in the basal and suprabasal keratinocytes is converted to previtamin D3 which by a nonenzymatic, thermal process gets converted to vitamin D3 or cholecalciferol. ${ }^{6}$ This then gets converted in the liver to 25 -hydroxyvitamin $\mathrm{D}$, which is the main determinant of vitamin D status, and eventually into its active form, 1,25 -dihydroxyvitamin $\mathrm{D}$ in the kidneys. ${ }^{6}$

Vitamin D mediates its effect through vitamin D receptors, which are widely present in most cells of the body, exerting a plethora of biological effects in addition to its major role in calcium homeostasis, such as inhibiting cellular proliferation and inducing terminal differentiation. ${ }^{5}$ This review focused on its effects on the immune system and the hair follicle.

In the immune system, vitamin D suppresses dendritic cell maturation and antigen presentation, and effectively promotes a tolerogenic $\mathrm{T}$-cell response by inducing $\mathrm{T}$ regulatory and Th2 cells and inhibiting Th1 and Th17 cells. ${ }^{7}$ With reduced levels of vitamin $D$, regulation of the immune system theoretically can be disrupted possibly promoting an autoimmune process.

In addition to the immune system, vitamin $\mathrm{D}$ receptors have also been demonstrated to be present in the hair follicle, specifically the outer root sheath and the mesodermal papilla wherein they are thought to initiate anagen. ${ }^{8}$ Thus, in alopecia areata, being an organ specific autoimmune of disease involving the hair, vitamin D may play a major role.

\section{Reduced levels of vitamin D and health outcomes}

Sun exposure, specifically UVB radiation, is the major determinant of vitamin D level. ${ }^{9}$ Less UVB exposure and consequently less vitamin $\mathrm{D}$ synthesis are associated with higher latitudes, early morning/late afternoon, winter season, low altitude/low lying areas, and presence of air pollution in urban areas. ${ }^{10}$ Skin phototype also affects vitamin D production; people with skin phototype VI can only produce $20 \%$ of the amount of vitamin D compared with a person with skin phototype I. ${ }^{9}$ Lifestyle factors including indoor/outdoor occupation or hobbies, clothing style, and obesity can affect vitamin D levels. ${ }^{9}$ Other groups at risk for low levels of vitamin
D are children, pregnant women, and the elderly. ${ }^{9}$ Drugs can also disrupt vitamin $\mathrm{D}$ metabolism and function; examples include antiepileptics such as phenytoin and carbamazepine, anti-infectives such as clotrimazole and rifampicin, and antiinflammatory agents like dexamethasone. ${ }^{11}$

Low vitamin D levels are known to cause bone disorders such as rickets and osteomalacia in children and adults, respectively, but recently has also been linked to a variety of diseases. Reduced levels of vitamin D have been shown to be significantly associated with adverse cardiovascular health outcome and with malignancies such as colorectal, pancreatic, gastrointestinal, and breast cancer. ${ }^{12}$ Autoimmune disorders such as type 1 diabetes mellitus, multiple sclerosis, rheumatoid arthritis, and systemic lupus erythematosus have also been associated with low vitamin D levels. ${ }^{13}$

With vitamin $\mathrm{D}$ playing a role in skin biology, association of low levels of vitamin $\mathrm{D}$ with various primarily dermatologic disorders has been found. A number of observational studies noted association of low vitamin $\mathrm{D}$ levels with psoriasis and chronic idiopathic urticaria. ${ }^{14-18} \mathrm{~A}$ recent systematic review and meta-analysis noted a significant association with reduced vitamin $\mathrm{D}$ levels and vitiligo. ${ }^{19} \mathrm{~A}$ systematic review noted low levels of vitamin $\mathrm{D}$ associated with atopic dermatitis; a few studies noted no association. ${ }^{20}$

\section{Significance of the Review}

Low vitamin $D$ levels have been associated with a variety of health outcomes, including autoimmune diseases. Alopecia areata is an organ-specific autoimmune disease of the hair and association with vitamin D levels has recently been studied. This review reported on the available studies regarding vitamin $\mathrm{D}$ levels and alopecia areata.

\section{OBJECTIVES}

The primary objective of this review was to determine the association between serum 25-hydroxyvitamin D levels in patients with alopecia areata compared to healthy controls.

The secondary objectives of this review were:

1. To determine the prevalence of vitamin D deficiency among alopecia areata patients and healthy controls

2. To describe the association of vitamin D levels among the clinical subtypes and severity of alopecia areata

\section{METHODS}

\section{Search strategy}

Literature search was done using the following electronic databases: MEDLINE, Cochrane Library, Trip Database, HERDIN (Health Research and Development Information Network), and Google Scholar covering the period from the date of creation of the databases until December 10, 2016. The following keywords were used: "alopecia areata" ,vitamin D", "25-hydroxyvitamin D", "1,25-dihydroxyvitamin D", "cholecalciferol", "calcidiol", and "calcitriol". 


\section{Searching other resources}

Review of the references of the retrieved articles was also done to search for other eligible studies that were not available in the abovementioned electronic databases.

\section{Study selection}

Observational studies that measured serum levels of 25-hydroxyvitamin D in alopecia areata patients compared to healthy controls were included in this review. Initial screening was done using titles and abstracts. Included studies then underwent full-text review.

\section{Data extraction}

A form for data extraction was filled out with the following information: author/s, study design, year and the country where the study was done, sample sizes for the alopecia areata and controls, sub-classification of alopecia areata, matching done for the controls, method of 25-hydroxyvitamin $\mathrm{D}$ determination, definition of vitamin $\mathrm{D}$ deficiency, and duration of blood sampling. The mean, standard deviation, and p-values of the levels of serum 25 -hydroxyvitamin $\mathrm{D}$ levels in $\mathrm{ng} / \mathrm{mL}$ were then collected for alopecia areata patients and controls. The prevalence of vitamin D deficiency for alopecia areata patients and controls were also noted.

\section{Quality Assessment of Included Studies}

A modified Newcastle Ottawa Scale was utilized to assess the quality of case control studies and for cross sectional studies to assess risk of bias. ${ }^{21,22}$ Three main sections were included in this critical appraisal: selection, comparability, and outcome. Highest possible score in the modified NOS was 10/10. Stratification of risk of bias was set as follows: high risk:0-4, moderate risk: 5-7 and low risk: 8-10.

\section{Statistical Analysis}

Statistical analysis was done using RevMan 5.3. For the continuous data on mean and SD of serum 25-hydroxyvitamin D levels, pooled weighted mean difference using random effects model was done with 95\% confidence interval. Heterogeneity was calculated using the $\mathrm{I}^{2}$ statistic. Forest plot was obtained and the test for overall effect using the $Z$ test was done. Funnel plot was also done to detect possible publication bias.

\section{RESULTS}

The electronic search through MEDLINE, Cochrane Library, Trip Database, HERDIN (Health Research and Development Information Network), and Google Scholar yielded 212 records. The articles were then screened using the title and abstract after which only 13 full text articles met the selection criteria. The 13 studies were then assessed for eligibility of which none was excluded. The study flow diagram in this review is shown in Figure 1.

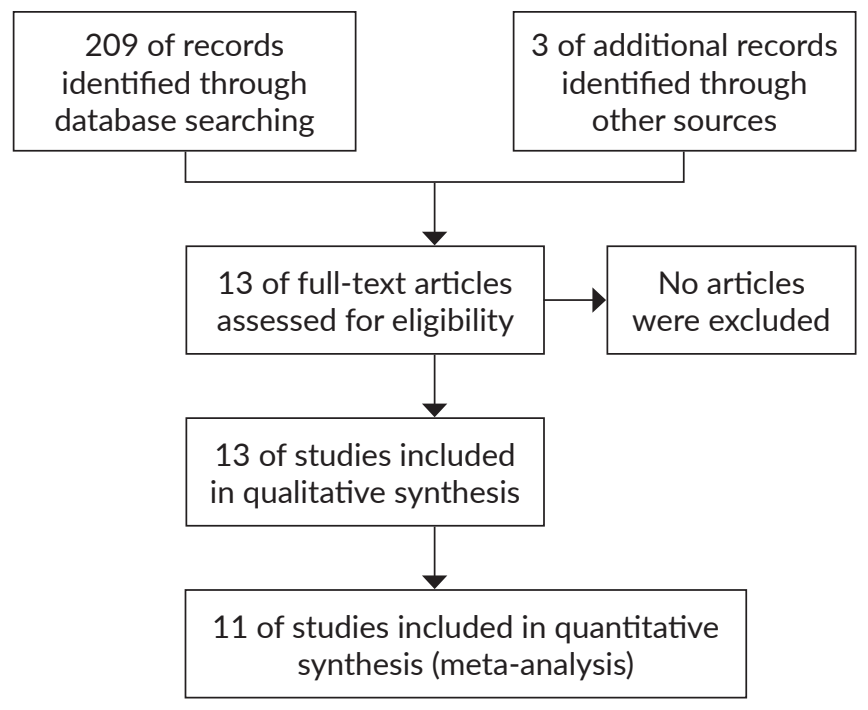

Figure 1. Study flow diagram.

The qualitative data extraction is shown in Table 1. The included articles were 9 cross sectional studies and 4 case control studies. Majority of the conducted studies were from the Middle East (Turkey, Egypt and Israel); other studies were from Italyand South Asia (India and Pakistan). ${ }^{23-35}$ Classification of alopecia areata by distribution was noted in all the studies mostly using the classification of single or multiple patches, ophiasis and alopecia totalis; with majority of of the studies using the SALT subclassification. ${ }^{23,25-27,29,32,33,36}$ Some of the studies also noted disease onset and duration. ${ }^{23,28,30,33}$ The studies were all age- and sex-matched or for those that did not do age and sex matching, there were no significant difference on the age and sex except for one study by Unal. ${ }^{37}$ Majority of the studies also accounted for the BMI, skin phototype, and other factors that can affect the vitamin D levels such as treatment with vitamin $\mathrm{D}$ supplements, steroid, topical vitamin $\mathrm{D}$, and phototherapy. Other excluded from most of the studies were those with autoimmune diseases and other dermatological diseases that can be affected by vitamin $\mathrm{D}$ such as atopic dermatitis and vitiligo. In summary, most of the studies had similar clinical characterization of alopecia areata and had similar exclusion criteria most of which were utilized to minimize said factors that can possibly affect vitamin D levels.

The methods of the determination of vitamin $\mathrm{D}$ levels in all studies were all immunoassay-based. Most of the studies utilized ELISA but a few used chemiluminescence and liquid chromatography although Unal did not mention the specific method for the vitamin D determination assay. $24,28,29,35$ This is a potential source also of heterogeneity since there were various methods used in determining the vitamin $\mathrm{D}$ levels. Majority of the studies reported vitamin D levels in $\mathrm{ng} / \mathrm{mL}$ but others reported levels in $\mathrm{nmol} / \mathrm{L}$ which can be converted by a factor of $0.4(1 \mathrm{nmol} / \mathrm{L}=0.4 \mathrm{ng} / \mathrm{mL})$. Most of the authors followed the Endocrine Society definition of 
vitamin $\mathrm{D}$ deficiency as 25- hydroxyvitamin $\mathrm{D}$ levels of less than $20 \mathrm{ng} / \mathrm{mL}$, vitamin D insufficiency at levels $21-29 \mathrm{ng} /$ $\mathrm{mL}$, and sufficient levels at $30-100 \mathrm{ng} / \mathrm{mL} .{ }^{5}$ Other authors defined $<20 \mathrm{ng} / \mathrm{mL}$ as insufficient, $<10 \mathrm{ng} / \mathrm{mL}$ as deficient, and $<30 \mathrm{ng} / \mathrm{mL}$ as deficient. ${ }^{23,25,38}$ This affected the reported prevalence in mentioned studies since different cut-off values were used. Duration of blood sampling was variable among the studies spanning various months.

Most of the studies noted that the serum 25-hydroxyvitamin D levels were significantly decreased in alopecia areata compared to healthy controls (Table 2). However, a few studies did not see a statistically significant difference in levels seen in alopecia areata compared to healthy controls. ${ }^{28,30,37}$ The mean levels in alopecia areata seen in the included studies ranged from $7.52 \mathrm{ng} / \mathrm{mL}$ to 26.6 $\mathrm{ng} / \mathrm{mL}$ compared to $9.8 \mathrm{ng} / \mathrm{mL}$ to $33.7 \mathrm{ng} / \mathrm{mL}$. [something lacking] There was increased prevalence of vitamin D deficiency in the studies that reported such measure. The correlation of severity of the alopecia with vitamin D levels was noted in most of the studies that reported this parameter except for 2 studies. ${ }^{24-27,29-32}$

Assessment of the quality of the included studies was done using the modified Newcastle Ottawa Scale for cross sectional studies as seen in Table 3. The studies included were of moderate to high risk of bias. The main source of potential bias for the studies came from the representativeness of the sample and sample size calculation; both parameters were not clearly stated. For the comparability, most of the studies accounted for the age, sex and other factors that can affect vitamin D levels except for the study done by Unal and Gonulalan. ${ }^{29}$ For the outcome, the study that was deemed of high risk of bias, that of d'Ovidio, ${ }^{35}$ was due to the statistical test done for the comparison of the serum levels of vitamin $\mathrm{D}$ between alopecia areata patients compared to healthy controls which was not explicitly stated. Another

study deemed of high risk of bias is that of Erpola et al. since the standard deviation was not reported. ${ }^{28}$ In summary, the included studies were of moderate to high risk of bias which is expected for observational studies especially in cross-sectional and case-control studies of which high quality studies are difficult to conduct, especially in the selection of the sample representative of the population.

For the meta-analysis (quantitative analysis), only 11 studies were included because the study by d'Ovidio et al. and Erpola et al. have missing data on the standard deviation (SD) as shown in Table 2.28,35 The SD is necessary to calculate for the weighted mean difference. A total of 916 patients were included in the meta-analysis. The pooled mean difference of the serum 25-hydroxyvitamin D levels between alopecia areata patients and healthy controls was $-9.55(95 \% \mathrm{CI},-10.51$ to -8.59$)$ with moderate heterogeneity $\left(\mathrm{I}^{2}=85 \%\right)$. Forest plot is shown in Figure 2 with the test for overall effect of $Z$ value of 19.54 $(p<0.00001)$. Funnel plot showed symmetry suggesting low risk of publication bias (Figure 3). In summary, reduced levels of serum 25-hydroxyvitamin D levels are associated with alopecia areata compared to healthy controls.

\section{DISCUSSION}

Based on the pooled mean difference of -9.55 (95\% CI, -10.51 to -8.59$)$ in this meta-analysis, there is a significant association of low levels of serum 25-hydroxyvitamin $\mathrm{D}$ levels in alopecia areata patients when compared to healthy controls. It is noted that 3 studies did not demonstrate said association, of which 2 studies were not included in the meta-analysis since the standard deviation were not reported by d'Ovidio and Erpolat et al. ${ }^{28,35}$ Those studies noted vitamin $\mathrm{D}$ levels in deficient levels (less than $20 \mathrm{ng} / \mathrm{mL}$ ) present in alopecia areata but said

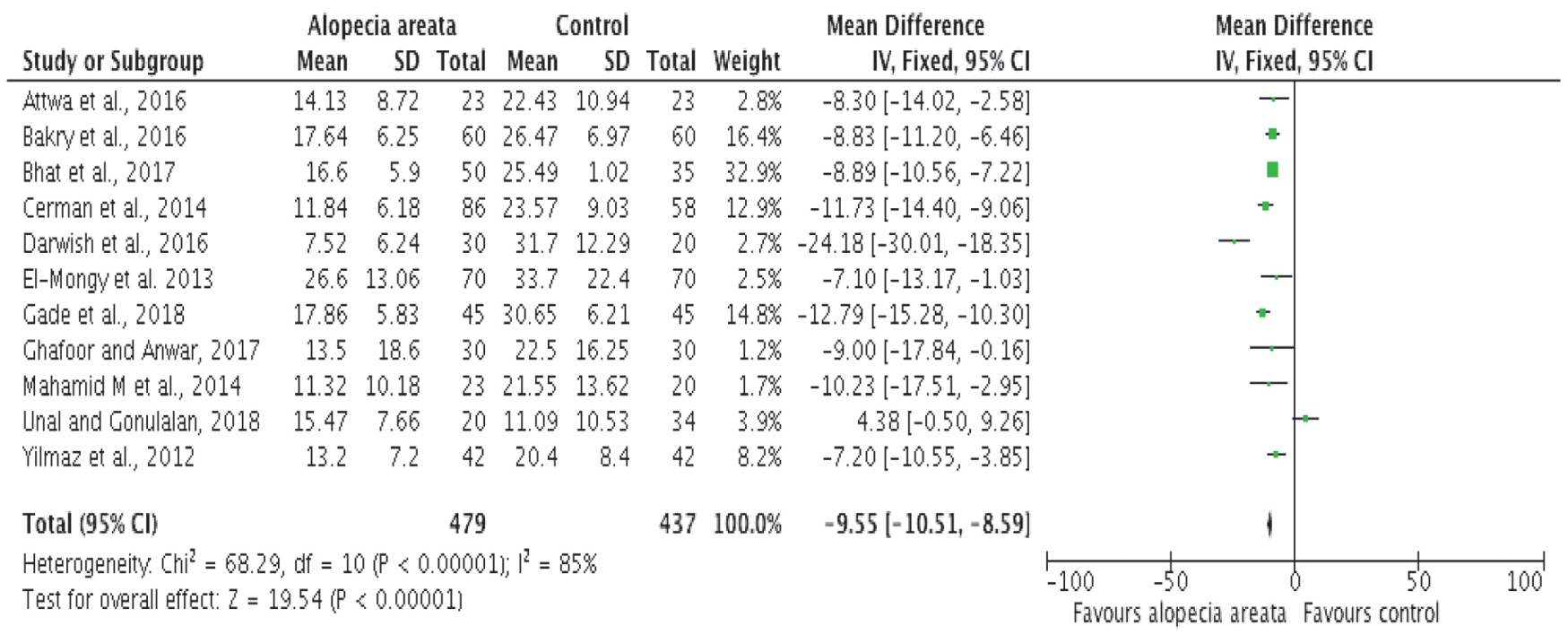

Figure 2. Forest plot showing pooled weighted mean difference of vitamin D levels among alopecia areata compared to healthy controls using the random effects model. 
Table 1. Qualitative data extraction on included studies

\begin{tabular}{|c|c|c|c|c|c|c|}
\hline \multirow{2}{*}{ Authors } & \multirow[b]{2}{*}{$\begin{array}{l}\text { Study } \\
\text { Design }\end{array}$} & \multirow[b]{2}{*}{ Year } & \multirow[b]{2}{*}{ Country } & \multicolumn{2}{|c|}{ Sample Size (n) } & \multirow[b]{2}{*}{$\begin{array}{l}\text { Type of Alopecia Areata } \\
\text { (Classification/Frequency) }\end{array}$} \\
\hline & & & & $\begin{array}{l}\text { Alopecia } \\
\text { Areata }\end{array}$ & Control & \\
\hline $\begin{array}{l}\text { Yilmaz } \\
\text { et al. }\end{array}$ & $\begin{array}{l}\text { Cross- } \\
\text { Sectional }\end{array}$ & 2012 & Turkey & 42 & 42 & $\begin{array}{l}\text { 1. Distribution: Patchy ( } 80.9 \%) \text {, Ophiasis (14.2\%), Totalis (4.7\%) } \\
\text { 2. SALT sub classification: } \mathrm{S}_{1}=71.4 \%, \mathrm{~S}_{2}=14.2 \%, \mathrm{~S}_{3}=7.4 \% \mathrm{~S}_{4}=4.7 \mathrm{~S}_{5}=2.3 \\
\text { 3. Onset: } \mathrm{New}(73.8 \%) \text { Old }(26.1 \%)\end{array}$ \\
\hline $\begin{array}{l}\text { d'Ovidio } \\
\text { et al. }\end{array}$ & $\begin{array}{l}\text { Cross- } \\
\text { Sectional }\end{array}$ & 2013 & Italy & 156 & 148 & $\begin{array}{l}\text { 1. Clinical appearance: Multilocularis (31.5\%), } \\
\text { Ophyasis (24.5\%), Totalis-Universalis ( } 24.5) \\
\text { 2. Activity: Stationary (43\%), Active ( } 57 \%)\end{array}$ \\
\hline $\begin{array}{l}\text { El-Mongy } \\
\text { et al. }\end{array}$ & $\begin{array}{l}\text { Case } \\
\text { control }\end{array}$ & 2013 & Egypt & 70 & 70 & $\begin{array}{l}\text { 1. Pattern of hair loss: Patchy (70\%), Alopecia, } \\
\text { Totalis/Alopecia Universalis (30\%) } \\
\text { 2. Disease Severity/SALT Score } \\
\text { Mild: S1 (42.9\%), Moderate: S2 (17.1\%), Severe: S3, S4, S5 (40\%) }\end{array}$ \\
\hline
\end{tabular}

\begin{tabular}{|c|c|c|c|c|c|c|}
\hline $\begin{array}{l}\text { Mahamid, } \\
\text { Met al. }\end{array}$ & $\begin{array}{l}\text { Cross- } \\
\text { Sectional }\end{array}$ & 2014 & Israel & 23 & 20 & Patchy (78.3\%), Extensive (21.7\%) \\
\hline $\begin{array}{l}\text { Cerman } \\
\text { et al. }\end{array}$ & $\begin{array}{l}\text { Cross- } \\
\text { Sectional }\end{array}$ & 2014 & Turkey & 86 & $\begin{array}{l}\text { (-) Control } \\
\text { (Healthy): } 58 \\
\text { (+) Control } \\
\text { (Vitiligo): } 44\end{array}$ & $\begin{array}{l}\text { 1. Clinical distribution: Multiple (59\%), Single (41\%) } \\
\text { 2. SALT sub classification: } \mathrm{S}_{1}=83 \%, \mathrm{~S}_{2}=17 \% \\
\text { 3. Onset: Old (58\%), New }(42 \%)\end{array}$ \\
\hline Bakry et al. & $\begin{array}{l}\text { Case- } \\
\text { control }\end{array}$ & 2016 & Egypt & 60 & 60 & $\begin{array}{l}\text { 1. Severity: Mild-3 or less patches, maximum diameter } \\
\text { of } 3 \mathrm{~cm} \text { or less or limited eyelashes or eyebrows) } \\
\text { Moderate-more than } 3 \text { patches with a maximum diameter of } 3 \mathrm{~cm} \text { or less } \\
\text { Severe-alopecia totalis or alopecia universalis } \\
\text { 2. Pattern of Hair Loss: Patchy, Ophiasis, } \\
\text { Alopecia Totalis, Alopecia universalis }\end{array}$ \\
\hline Attwa et al. & $\begin{array}{l}\text { Cross- } \\
\text { sectional }\end{array}$ & 2016 & Egypt & 23 & 23 & $\begin{array}{l}\text { 1. Severity of AA } \\
\text { Mild: S1 (61\%), Moderate: S2 (13\%), Severe: S3, S4, S5 (26\%) } \\
\text { 2. Pattern of AA } \\
\text { Single patch, multiple patches, alopecia totalis, alopecia universalis }\end{array}$ \\
\hline $\begin{array}{l}\text { Darwish } \\
\text { et al. }\end{array}$ & $\begin{array}{l}\text { Case- } \\
\text { control }\end{array}$ & 2016 & Egypt & 30 & 20 & $\begin{array}{l}\text { 1. Severity of AA } \\
\text { Mild: S1 (33.3\%), Moderate: S2 (23.3\%), Severe: S3, S4, S5 (43.3\%) } \\
\text { 2. Pattern of hair loss: Patchy (66.7\%); AT and AU (33.3\%) } \\
\text { 3. Disease duration: < } 6 \text { months (50\%); > } 6 \text { months }(50 \%)\end{array}$ \\
\hline $\begin{array}{l}\text { Ghafoor } \\
\text { and Anwar }\end{array}$ & $\begin{array}{l}\text { Case- } \\
\text { control }\end{array}$ & 2017 & Pakistan & 30 & 30 & $\begin{array}{l}\text { 1. Disease duration: }<3 \text { months }(0.9 \%), 3-12 \text { months }(33.3 \%) \\
\text { 12-24 months }(20 \%), 2-5 \text { years }(20 \%),>5 \text { years }(16.66 \%) \\
\text { 2. Pattern of alopecia: Unifocal }(20 \%) \text {, Multifocal }(50 \%) \text {, Ophiasis } \\
\text { (0.9\%), Alopecia universalis }(6.67 \%), \text { Alopecia totalis }(13.33 \%) \\
\text { 3. SALT Score: S1 }(13.33 \%), \text { S2 }(23.33 \%), \text { S3 }(40 \%), \text { S4 }(3.33 \%), \text { S5 }(20 \%)\end{array}$ \\
\hline $\begin{array}{l}\text { Erpolat } \\
\text { et al. }\end{array}$ & $\begin{array}{l}\text { Cross- } \\
\text { sectional }\end{array}$ & 2017 & Turkey & 41 & 32 & $\begin{array}{l}\text { 1. Disease duration (in months): }<1(31.7 \%) \\
\text { 1-3 (24.4\%), } 4-6(12.2 \%),>6(31.7 \%) \\
\text { 2. Involvement: Single (36.6\%), Multiple (63.4\%) }\end{array}$ \\
\hline Bhat et al. & $\begin{array}{l}\text { Cross } \\
\text { sectional }\end{array}$ & 2017 & India & 50 & 35 & $\begin{array}{l}\text { 1. Number of alopecic patches: Single (58\%), Multiple (42\%) } \\
\text { 2. SALT Score: S1 (76\%), S2 (24\%) }\end{array}$ \\
\hline
\end{tabular}

\begin{tabular}{|c|c|c|c|c|c|c|}
\hline $\begin{array}{l}\text { Unal and } \\
\text { Gonulalan }\end{array}$ & $\begin{array}{l}\text { Cross } \\
\text { sectional }\end{array}$ & 2018 & Turkey & 20 & 34 & $\begin{array}{l}\text { 1. Number of patches: All had multiple patches } \\
\text { 2. SALT Score: S1 (30\%), S2 (45\%), S3 (25\%) }\end{array}$ \\
\hline Gade et al. & $\begin{array}{l}\text { Cross } \\
\text { sectional }\end{array}$ & 2018 & India & 45 & 45 & 1. SALT Score: Frequency of SALT Score not reported \\
\hline
\end{tabular}




\section{Controls}

Matched for age (AA: 30.8 (8.2), C: 29.3 (7.4) sex (F>M)

Normal renal and liver function, no vitamin D/ calcium/steroid medication, nonsmokers

Matched for age (AA: 37.8, C: 34.5) and sex (F>M)

No steroid therapy for at least 1 year, not overweight
Method of

Did not match for age and sex

Adequacy of sun exposure

Excluded patients with vitamin D deficiency, diseases affecting

its level, on vitamin D supplements, on PUVA treatment
ELISA

Chemiluminescence assay
25-Hydroxy-Vitamin D Determination
25-Hydroxy

Vitamin D levels

Insufficient: $<$

$50 \mathrm{nmol} / \mathrm{L}(20 \mathrm{ng} / \mathrm{mL})$
Duration of Blood Sampling

June - September

2010

October - March 2010 and 2012

EIA/ELISA

True deficiency: $20 \mathrm{ng} / \mathrm{mL}$

January - June

Deficiency: $<30 \mathrm{nmol} / \mathrm{L}$ 2011

(12ng/mL)

Insufficiency: $30-75 \mathrm{nmol} / \mathrm{L}$

(12-30ng/mL)

Sufficient: $>75 \mathrm{nmol} / \mathrm{L}$

(30ng/mL)
Insufficient: $<30 \mathrm{ng} / \mathrm{mL}$

Deficient: $<20 \mathrm{ng} / \mathrm{mL}$

Deficient $\leq 20 \mathrm{ng} / \mathrm{mL}$

March 2010 -

May 2011

November 21 -

March 212013
Matched for age (AA:24.2 (12.3) C: 7 (11.26)) and sex (M>F) BMI

Matched for age (AA: 32.21(9.6) C:33.64 (11.51)) and sex

BMI

Geographical area (metropolitan area of Istanbul), White-skinned

\section{Commercial enzyme} immunoassay

Liquid

chromatography/

mass spectrophotometer

Matched for age, gender, BMI $\quad$ ELISA

Skin Phototypes III and IV

Sun exposure quantified $<2$ or $>2$ hours

ELISA

Deficient: $<50 \mathrm{nmol} / \mathrm{L}$

October 2013

(20ng/mL)

- March 2014

Insufficient: $50-75 \mathrm{nmo} / \mathrm{L}$

(20-30ng/mL)

Sufficient: $>30 \mathrm{ng} / \mathrm{mL}$

No significant difference in age and sex between cases and controls Excluded those taking nutritional supplement, pregnant, diseases that could alter vitamin D status (autoimmune, atopy or affecting the hair)

\section{ELISA}

Deficiency: < 10ng/mL

Insufficiency: 10-30ng/mL November 2014

Sufficiency: $>30 \mathrm{ng} / \mathrm{mL}$

\begin{tabular}{|c|c|c|c|}
\hline $\begin{array}{l}\text { No significant difference in age and sex between cases and controls } \\
\text { Excluded those taking supplements for the past } 6 \text { months (vitamin D, } \\
\text { vitamin B, folic acid, calcium), treated with topical vitamin D analog, } \\
\text { known state of vitamin D deficiency, associated diseases (vitiligo, } \\
\text { psoriasis, SLE, renal disease, liver disease, cancers and autoimmune) }\end{array}$ & ELISA & Not mentioned & Not mentioned \\
\hline $\begin{array}{l}\text { Matched for age and sex } \\
\text { Excluded those who have taken systemic steroids, calcium and } \\
\text { vitamin D supplementations, bisphosphonates, immunosuppressive } \\
\text { agents, phototherapy, pregnant and lactating women, autoimmune } \\
\text { disorders, sarcoidosis, renal disease, malignancy and malabsorption }\end{array}$ & Enzyme immunoassay & $\begin{array}{l}\text { Deficiency }<20 \mathrm{ng} / \mathrm{dL} \\
\text { Insufficiency } 21-29 \mathrm{ng} / \mathrm{dL} \\
\text { Sufficiency }>30 \mathrm{ng} / \mathrm{dL}\end{array}$ & $\begin{array}{l}\text { October } 2014 \\
\text { - March } 2015\end{array}$ \\
\hline $\begin{array}{l}\text { No significant difference in age and sex between cases and controls } \\
\text { Exclusion based on oral vitamin D supplementation, } \\
\text { major cardiovascular, liver, kidney or digestive disease; } \\
\text { treatment for AA } 1 \text { month before testing }\end{array}$ & $\begin{array}{l}\text { High performance } \\
\text { liquid } \\
\text { chromatography }\end{array}$ & $\begin{array}{l}\text { Deficient }<20 \mathrm{ng} / \mathrm{mL} \\
\text { Insufficient } 20-30 \mathrm{ng} / \mathrm{mL} \\
\text { Sufficient }>30 \mathrm{ng} / \mathrm{mL}\end{array}$ & $\begin{array}{l}\text { October } 2010 \\
\text { - March } 2011\end{array}$ \\
\hline $\begin{array}{l}\text { Age and sex matched controls } \\
\text { BMI, Residence (Urban and rural) } \\
\text { Exclusion criteria: any dermatologic, systemic, autoimmune } \\
\text { illness, with other types of alopecia, received treatment } \\
\text { for the past } 4 \text { weeks (steroids, immunosuppressants, } \\
\text { vitamin D, topical vitamin D); pregnant, BMI > } 25\end{array}$ & $\begin{array}{l}\text { Chemiluminescence } \\
\text { method }\end{array}$ & Deficiency <30ng/mL & $\begin{array}{l}\text { May } 2015- \\
\text { October } 2015\end{array}$ \\
\hline $\begin{array}{l}\text { Pediatric patients but did not control for age and sex; BMI }<25 \\
\text { Exclusion criteria: any dermatologic disease, systemic } \\
\text { disease, sunscreen use and smoking. Any topical } \\
\text { of systemic treatment within } 4 \text { weeks }\end{array}$ & Not mentioned & Deficiency <20ng/mL & $\begin{array}{l}\text { November } 2015 \\
\text { - March } 2016\end{array}$ \\
\hline $\begin{array}{l}\text { Matched for age, sex, BMI } \\
\text { Exclusion criteria: on any topical or systemic medication for } \\
\text { the past month before recruitment, smoking, alcoholism, } \\
\text { obesity, pregnancy, malignancies, hepatic and renal } \\
\text { disease, cardiovascular disease, endocrine disorders, } \\
\text { autoimmune, infectious and inflammatory diseases }\end{array}$ & ELISA & Not mentioned & $\begin{array}{l}\text { Winter period } \\
\text { (dates not } \\
\text { mentioned) }\end{array}$ \\
\hline
\end{tabular}


Table 2. Comparison of the levels of serum vitamin D levels and prevalence of vitamin

\begin{tabular}{|c|c|c|c|c|c|c|}
\hline \multirow[t]{2}{*}{ Authors, Year } & \multicolumn{2}{|c|}{$\begin{array}{c}\text { Serum 25-hydroxyvitamin D } \\
\text { (ng/mL) (Mean, SD) }\end{array}$} & \multirow[t]{2}{*}{ p-value } & \multicolumn{2}{|c|}{$\begin{array}{c}\text { Prevalence of Vitamin D } \\
\text { Deficiency (\%) }\end{array}$} & \multirow{2}{*}{$\begin{array}{l}\text { Correlation between severity of } \\
\text { alopecia areata and vitamin D levels }\end{array}$} \\
\hline & Alopecia Areata & Controls & & Alopecia Areata & Controls & \\
\hline Yilmaz et al. 2012 & $13.2(7.2)$ & $20.4(8.4)$ & $<0.001$ & 85 & r.m. & No data \\
\hline d'Ovidio et al., 2013 & $23.2(?)$ & $24.8(11.2)$ & $<0.20$ & 42.4 & 29.5 & No data \\
\hline $\begin{array}{l}\text { El-Mongy } \\
\text { et al., } 2013\end{array}$ & $26.6(13.06)$ & $33.7(22.4)$ & 0.023 & $\begin{array}{l}8.6 \\
\text { *Insufficiency: } \\
62.9\end{array}$ & $\begin{array}{l}7.1 \\
\text { *Insufficiency: } \\
44.3\end{array}$ & $\begin{array}{l}\text { Noted no significant linear correlation } \\
\text { between serum } 25 \text { hydroxyvitamin } D \\
\text { levels and the duration or severity of } \\
\text { AA (no specific values mentioned) }\end{array}$ \\
\hline $\begin{array}{l}\text { Mahamid, M et al., } \\
2014\end{array}$ & $11.32(10.18)$ & $21.55(13.62)$ & $<0.05$ & 69.5 & 25 & No data \\
\hline $\begin{array}{l}\text { Cerman et al., } \\
2014\end{array}$ & $11.84(6.18)$ & $\begin{array}{l}\text { (+) Control-Vitiligo: } \\
\text { 16.15 (7.93) } \\
\text { (-) Control: } \\
23.57(9.03)\end{array}$ & $<0.001$ & 91 & $\begin{array}{l}\text { (+) Control- } \\
\text { Vitiligo: } 71 \\
\text { (-) Control: } 33\end{array}$ & $\begin{array}{l}\text { SALT Scores were significantly } \\
\text { negatively correlated with vitamin D } \\
\text { concentration }(r=0.409, p<0.001)\end{array}$ \\
\hline Bakry et al., 2016 & $17.64(6.25)$ & $26.47(6.97)$ & $<0.001$ & 83.30 & 23.30 & $\begin{array}{l}\text { Noted no significant relationship } \\
\text { between vitamin d levels and } \\
\text { disease duration and recurrence }\end{array}$ \\
\hline Attwa et al., 2016 & $14.13(8.72)$ & $22.43(10.94)$ & 0.01 & $\begin{array}{l}21.7 \\
\text { *Insufficiency: } \\
69.6\end{array}$ & $\begin{array}{l}13 \\
\text { *Insufficiency: } \\
39.1\end{array}$ & $\begin{array}{l}\text { Correlation between degree/severity } \\
\text { of } A A \text { and vitamin } D \text { deficiency } \\
\text { but not with clinical pattern }\end{array}$ \\
\hline Darwish et al., 2016 & $7.52(6.24)$ & $31.70(12.29)$ & $<0.001$ & No data & No data & No data \\
\hline $\begin{array}{l}\text { Ghafoor and } \\
\text { Anwar, } 2017\end{array}$ & $13.5(18.6)$ & $22.5(16.25)$ & 0.001 & No data & No data & $\begin{array}{l}\text { Mentioned that lower vitamin D levels } \\
\text { in patients with higher SALT Score } \\
\text { were seen (no statistical test done) }\end{array}$ \\
\hline Erpolat et al., 2017 & 8.1 (?) & $9.8(?)$ & 0.508 & 93.8 & 85.3 & No data \\
\hline Bhat et al., 2017 & $16.6(5.9)$ & $25.49(1.02)$ & $<0.001$ & No data & No data & $\begin{array}{l}\text { SALT Scores }(r=-0.73, p<0.001) \\
\text { and number of patches }(r=-0.670, \\
p<0.001) \text { were significantly negatively } \\
\text { correlated with vitamin D levels }\end{array}$ \\
\hline $\begin{array}{l}\text { Unal and } \\
\text { Gonulalan, } 2018\end{array}$ & $15.47(7.66)$ & $11.09(10.53)$ & 0.084 & No data & No data & $\begin{array}{l}\text { SALT Scores }(r=-0.831, p<0.001) \\
\text { number of patches }(r=-0.989, \\
p<0.001) \text { and disease duration }(-0.997, \\
p<0.001) \text { were significantly negatively } \\
\text { correlated with vitamin D levels }\end{array}$ \\
\hline Gade et al., 2018 & $17.86(5.83)$ & $30.65(6.21)$ & 0.0001 & No data & No data & $\begin{array}{l}\text { Disease severity was significantly } \\
\text { negatively correlated with vitamin } \\
\text { D levels }(r=-0.714, p=0.001)\end{array}$ \\
\hline
\end{tabular}

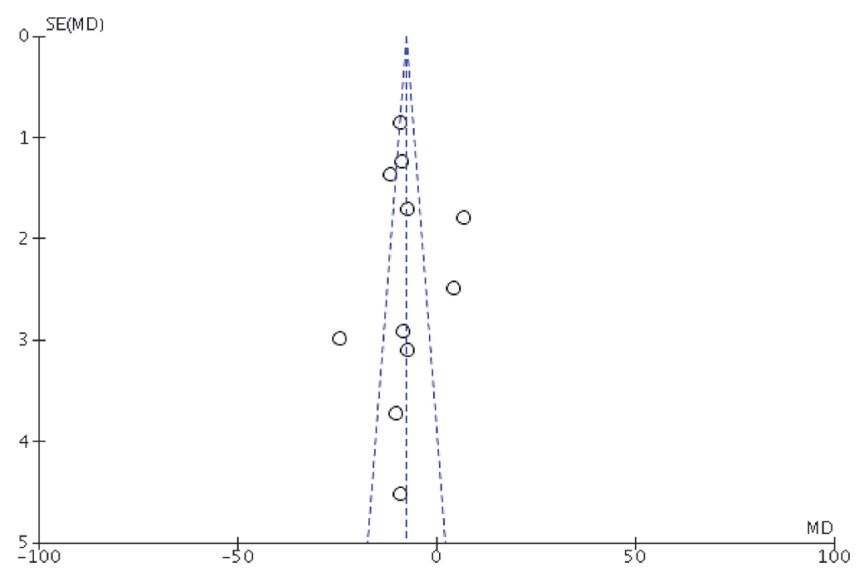

Figure 3. Funnel plot of the standard error against the mean differences of serum 25-hydroxyvitamin D levels among included studies. levels were also present in the normal/healthy controls of the population in Italy and Turkey, hence the lower levels being not statistically significant when compared. ${ }^{28,35,37}$ The prevalence of vitamin D deficiency $(<20 \mathrm{ng} / \mathrm{mL})$ among alopecia areata in the study population that reported such ranged from $42.4 \%$ to $93.8 \%$ compared to controls that ranged from $29.5 \%$ to $85.3 \%$ (Table 2). For the studies that used vitamin $\mathrm{D}$ deficiency with a lower cut off (10ng/mL and $12 \mathrm{ng} / \mathrm{mL})$, prevalence were lower at $8.6 \%$ to $21.7 \%$ in alopecia areata compared to $7.1 \%$ to $13 \%$ in controls. ${ }^{30,38}$ The high prevalence of vitamin D deficiency can also possibly explain why some studies did not report a statistically significant difference of vitamin $\mathrm{D}$ levels in alopecia areata patients.

With the reduced levels of vitamin D in alopecia areata, the studies also investigated the association of vitamin $\mathrm{D}$ levels in relation to the clinical severity with the main parameters being the number of patches (single or multiple), clinical variant (patchy, ophiasis, alopecia totalis, alopecia universalis), disease duration, and the use of SALT (Severity of Alopecia Tool) Score. Increased number of patches were 
Table 3. Assessment of bias risk using the modified Newcastle-Ottawa for cross sectional studies

\begin{tabular}{|c|c|c|c|c|c|c|c|c|c|c|}
\hline & Criteria & $\begin{array}{l}\text { Yilmaz } \\
\text { et al., } \\
2012\end{array}$ & $\begin{array}{c}\text { d'Ovidio } \\
\text { et al., } \\
2013\end{array}$ & $\begin{array}{l}\text { Mahamid } \\
\text { et al., } \\
2014\end{array}$ & $\begin{array}{c}\text { Cerman } \\
\text { et al., } \\
2014\end{array}$ & $\begin{array}{l}\text { Attwa } \\
\text { et al., } \\
2016\end{array}$ & $\begin{array}{c}\text { Erpolat } \\
\text { et al., } \\
2017\end{array}$ & $\begin{array}{l}\text { Bhat } \\
\text { et al., } \\
2017\end{array}$ & $\begin{array}{c}\text { Unal and } \\
\text { Gonulalan, } \\
2018\end{array}$ & $\begin{array}{l}\text { Gade } \\
\text { et al., } \\
2018\end{array}$ \\
\hline \multirow[t]{4}{*}{ Selection } & $\begin{array}{l}\text { Representativeness } \\
\text { of the sample }\end{array}$ & - & - & - & - & - & - & - & - & - \\
\hline & Sample Size & - & - & - & - & - & - & - & - & ${ }^{*}$ \\
\hline & Non-respondents & NA & NA & NA & NA & NA & NA & NA & NA & NA \\
\hline & $\begin{array}{l}\text { Ascertainment } \\
\text { of exposure }\end{array}$ & $* *$ & $* *$ & $* *$ & $* *$ & $* *$ & $* *$ & $* *$ & $* *$ & $* *$ \\
\hline Comparability & $\begin{array}{l}\text { Subjects in different } \\
\text { outcome groups } \\
\text { are comparable }\end{array}$ & $*$ & $* *$ & $* *$ & $* *$ & $* *$ & $* *$ & $* *$ & - & $* *$ \\
\hline \multirow[t]{3}{*}{ Outcome } & $\begin{array}{l}\text { Assessment of } \\
\text { the outcome }\end{array}$ & NA & NA & NA & NA & NA & NA & NA & NA & NA \\
\hline & Statistical test & $*$ & - & $*$ & $*$ & $*$ & - & $*$ & $*$ & $*$ \\
\hline & Risk of Bias & Moderate & High & Moderate & Moderate & Moderate & High & Moderate & High & Moderat \\
\hline
\end{tabular}

Table 4. Assessment of risk of bias using the Newcastle Ottawa for case-control studies

\begin{tabular}{|c|c|c|c|c|c|}
\hline & Criteria & $\begin{array}{l}\text { El-Mongy et al. } \\
2013\end{array}$ & $\begin{array}{c}\text { Bakry et al., } \\
2016\end{array}$ & $\begin{array}{l}\text { Darwish et al., } \\
2016\end{array}$ & $\begin{array}{l}\text { Ghafoor and } \\
\text { Anwar, } 2017\end{array}$ \\
\hline \multirow[t]{4}{*}{ Selection } & Case definition adequacy & $*$ & $*$ & $*$ & $*$ \\
\hline & Representativeness of the cases & * & * & * & * \\
\hline & Selection of controls & - & - & - & - \\
\hline & Definition of controls & $*$ & * & * & * \\
\hline Comparability & Subjects in different outcome groups are comparable & * & $* *$ & * & ** \\
\hline \multirow[t]{4}{*}{ Outcome } & Ascertainment of exposure & * & * & * & ${ }^{*}$ \\
\hline & Same method of ascertainment for cases and controls & * & $*$ & * & * \\
\hline & Non response rate & - & - & - & - \\
\hline & Risk of Bias & Moderate & Moderate & Moderate & Moderate \\
\hline
\end{tabular}

noted to be negatively correlated with vitamin $\mathrm{D}$ levels in 2 studies. ${ }^{25,29}$ Disease duration was also correlated, with longer disease duration having lower vitamin D levels. ${ }^{29,30}$ SALT Scores were negatively correlated with vitamin D levels in 5 studies. ${ }^{25-27,36,38}$ However 2 studies did not show this relationship of disease duration and alopecia severity with vitamin D levels. ${ }^{30,31}$ This trend of having lower vitamin $\mathrm{D}$ levels in the more severe forms of alopecia areata (ie multiple patches, alopecia totalis, alopecia universalis, higher SALT Scores) in the majority of the studies that reported this can target these certain patients for vitamin $\mathrm{D}$ level determination.

The low levels of serum 25-hydroxyvitamin D in alopecia areata can be possibly explained by the role of vitamin $\mathrm{D}$ in the immune system and the hair growth cycle. A review noted that vitamin $\mathrm{D}$ suppresses dendritic cell maturation and antigen presentation, and effectively promotes a tolerogenic $\mathrm{T}$-cell response by inducing $\mathrm{T}$ regulatory and Th2 cells and inhibiting Th1 and Th17 cells. ${ }^{7}$ With reduced levels of vitamin $\mathrm{D}$, regulation of the immune system theoretically can be disrupted possibly promoting an autoimmune process. Other autoimmune diseases have been associated with reduced levels of vitamin D such as type 1 diabetes mellitus, multiple sclerosis, rheumatoid arthritis, systemic lupus erythematosus, and systemic sclerosis. ${ }^{13}$ Even in skin diseases of which the immune system is thought to play a role, decreased vitamin $\mathrm{D}$ levels are also present such as in psoriasis, chronic idiopathic urticaria, vitiligo, and atopic dermatitis. ${ }^{14-20}$

Aside from being present in the immune system, vitamin $\mathrm{D}$ receptors have also been found in the hair follicle, specifically, the outer root sheath and mesodermal papillae. There are increased vitamin $\mathrm{D}$ receptors during late anagen and catagen which stimulate differentiation of the keratinocytes ultimately promoting the hair growth cycle. 7 This proposed role in hair growth cycle in addition to regulating the immune system may explain lower vitamin $\mathrm{D}$ levels and higher vitamin $\mathrm{D}$ deficiency prevalence in alopecia areata compared to vitiligo as seen in one study. ${ }^{24}$

\section{Limitations of the Review}

Vitamin D levels are mainly affected by sun exposure, which in turn is affected by a number of factors, including geography, season and cultural factors (sun avoidance, long clothing). Since majority of the studies were conducted in the Middle East (Turkey, Egypt and Israel), South Asia (India and Pakistan), and Europe (Italy), the association shown here in this review can possibly be only applicable to said regions. Another issue is the variety of the methods used to determine the vitamin $\mathrm{D}$ levels, which can possibly explain the variation of the range of the vitamin D levels seen in this study. All of these factors can possibly explain the moderate heterogeneity seen in this meta-analysis. 


\section{CONCLUSION}

In conclusion, there is reduced serum 25-hydroxyvitamin $\mathrm{D}$ levels in alopecia areata compared to healthy controls and vitamin $\mathrm{D}$ deficiency is more prevalent in alopecia areata compared to healthy controls. In studies that did not note a similar association, the high prevalence of low vitamin D levels in healthy controls were noted. There was also a trend of having lower vitamin $\mathrm{D}$ levels in the more severe forms of alopecia areata (ie multiple patches, alopecia totalis, alopecia universalis, higher SALT Scores) in the majority of the studies that reported said parameter.

\section{Implications for clinical practice}

Since there is significant association of low vitamin D levels in alopecia areata, determination of serum 25-hydroxyvitamin D levels may be considered especially in patients with severe disease such as ophiasis, alopecia totalis/universalis, and higher SALT Scores.

\section{Implications for future research}

Vitamin D levels are largely affected by geographical location, skin phototype, lifestyle, and cultural practices, which can be different depending on the region. Further studies may be done in other regions of the world in order to determine if the same association exists.

Also, with low vitamin D levels and increased prevalence of vitamin $\mathrm{D}$ deficiency in alopecia areata patients, clinical trials for supplementation with vitamin $\mathrm{D}$ may be done to determine if the intervention might modify the course of the disease. In other autoimmune dermatologic disorders associated with reduced vitamin $\mathrm{D}$ levels, supplementation is already being investigated. A meta-analysis on vitamin D supplementation showed decreased severity of atopic dermatitis. ${ }^{39} \mathrm{In}$ chronic urticaria, vitamin $\mathrm{D}$ supplementation improved symptoms and quality of life. ${ }^{18,40-42}$ In psoriasis, vitamin $\mathrm{D}$ supplementation was shown to improve the symptoms. ${ }^{43,44}$ A pilot open-label study noted increased pigmentation rates with vitamin $\mathrm{D}$ supplementation in vitiligo patients. ${ }^{43}$

\section{Statement of Authorship}

All authors approved the final version submitted.

\section{Author Disclosure}

All authors declared no conflict of interest.

\section{Funding Source}

This paper was funded by the authors. No external funding agency.

\section{REFERENCES}

1. Alkhalifah A, Alsantali A, Wang E, McElwee KJ, Shapiro J. Alopecia areata update. Part I. Clinical picture, histopathology, and pathogenesis.
J Am Acad Dermatol. 2010;62(2):177-88, quiz 189-90. doi: 10.1016/j. jaad.2009.10.032

2. Sperling L, Sinclair R, Shabrawi-Caelen L. Alopecias. In: Bolognia J, Jorizzo J, Schaffer J, eds. Dermatology. 4th ed. Elsevier Saunders; 2018:1162-74.

3. de Berker D, Higgins C, Jahoda C, Christiano A. Biology of Hair and Nails. In: Bolognia J, Jorizzo J, Schaffer J, eds. Dermatology. 3rd ed. Elsevier Saunders; 2012:1075-92.

4. Elder D, Elenitsas R, Rubin A, Ioffreda M, Miller J, Miller III FO. Atlas and Synopsis of Lever's Histopathology of the Skin. Lippincott Williams and Wilkins; 2013.

5. Holick MF, Binkley NC, Bischoff-Ferrari HA, et al. Evaluation, treatment, and prevention of vitamin D deficiency: An endocrine society clinical practice guideline. J Clin Endocrinol Metab. 2011;96(7):191130. doi:10.1210/jc.2011-0385.

6. Vanchinathan V, Lim HW. A dermatologist's perspective on vitamin D. Mayo Clin Proc. 2012;87(4):372-80. doi:10.1016/j. mayocp.2011.12.010

7. Mostafa WZ, Hegazy RA. Vitamin D and the skin: Focus on a complex relationship: A review. J Adv Res. 2015;6(6):793-804. doi:10.1016/j. jare.2014.01.011.

8. Amor KT, Rashid RM, Mirmirani P. Does D matter? The role of vitamin $\mathrm{D}$ in hair disorders and hair follicle cycling. Dermatol Online J. 2010;16(2):3...

9. Lips P, van Schoor NM, de Jongh RT. Diet, sun, and lifestyle as determinants of vitamin D status. Ann N Y Acad Sci. 2014;1317:92-8. doi: 10.1111 /nyas. 12443

10. Wacker M, Holick MF. Sunlight and Vitamin D: A global perspective for health. Dermatoendocrinol. 2013;5(1):51-108. doi: .10.4161/ derm. 24494

11. Gröber U, Kisters K. Influence of drugs on vitamin D and calcium metabolism. Dermatoendocrinol. 2012;4(2):158-66. doi: 10.4161/ derm.20731.

12. LoPiccolo MC, Lim HW. Vitamin D in health and disease. Photodermatol Photoimmunol Photomed. 2010;26:224-29.

13. Antico A, Tampoia M, Tozzoli R, Bizzaro N. Can supplementation with vitamin $\mathrm{D}$ reduce the risk or modify the course of autoimmune diseases? A systematic review of the literature. Autoimmun Rev. 2012;12(2):127-36. doi: 10.1016/j.autrev.2012.07.007.

14. Gisondi P, Rossini M, Di Cesare A, et al. Vitamin D status in patients with chronic plaque psoriasis. Br J Dermatol. 2012;166(3):505-10. doi:10.1111/j.1365-2133.2011.10699.x.

15. Orgaz-Molina J,Buendía-Eisman A,Arrabal-Polo MA, RuizJC,AriasSantiago S. Deficiency of serum concentration of 25-Hydroxyvitamin D in psoriatic patients: A case-Control study. J Am Acad Dermatol. 2012; 67(5):931-8. doi: 10.1016/j.jaad.2012.01.040.

16. Zuchi MF, De P, Azevedo O, et al. COMMUNICATION Serum levels of 25-hydroxy vitamin D in psoriatic patients *. An Bras Dermatol. 2015;90(3):430-2. doi:10.1590/abd1806-4841.20153524.

17. Movahedi M, Tavakol M, Hirbod-Mobarakeh A, et al. Vitamin D Deficiency in Chronic Idiopathic Urticaria. Iran J Allergy Asthma Immunol April Iran J Allergy Asthma Immunol, Spring. 2015;14(2):222-7.

18. Rasool R, Masoodi KZ, Shera IA, et al. Chronic urticaria merits serum vitamin $\mathrm{D}$ evaluation and supplementation; a randomized case control study. World Allergy Organ J. 2015;8(15). doi:10.1186/s40413-0150066-z.

19. Upala S, Sanguankeo A. Low 25-hydroxyvitamin D levels are associated with vitiligo: a systematic review and meta-analysis. Photodermatol Photoimmunol Photomed. 2016;32(4):181-90. doi:10.1111/ phpp.12241.

20. Mesquita K de C, Igreja AC de SM, Costa IMC. Atopic dermatitis and vitamin D: facts and controversies. An Bras Dermatol. 2013;88(6):94553. doi:10.1590/abd1806-4841.20132660.

21. Wells G, Shea B, O'Connell D, et al. The Newcastle-Ottawa Scale (NOS) for assessing the quality of nonrandomised studies in metaanalyses [Internet]. 2014 (cited Dec. 1, 2016] Available from http:// www.ohri.ca/programs/clinical_epidemiology/oxford.asp. 
22. Herzog R, Álvarez-Pasquin MJ, Díaz C, et al. Are healthcare workers' intentions to vaccinate related to their knowledge, beliefs and attitudes? a systematic review. BMC Public Health. 2013;13(1):154. doi:10.1186/1471-2458-13-154.

23. Yilmaz N, Serarslan G, Gokce C. Vitamin D Concentrations are Decreased in Patients with Alopecia Areata. Vitam Trace Elem. 2012;01(04):1-4. doi:10.4172/2167-0390.1000105.

24. Aksu Cerman A, Sarikaya Solak S, Kivanc Altunay I. Vitamin D deficiency in alopecia areata. Br J Dermatol. 2014;170(6):1299-304. doi:10.1111/bjd.12980.

25. Bhat $Y$, Latif $I$, Malik R, et al. Vitamin $D$ level in alopecia areata. Indian J Dermatol. 2017;62:407-10. doi:DOI: 10.4103/ijd.IJD_677_16.

26. Gade VKV, Mony A, Munisamy M, Chandrashekar L, Rajappa M. An investigation of vitamin D status in alopecia areata. Clin Exp Med. 2018;(0123456789). doi:10.1007/s10238-018-0511-8.

27. Ghafoor R, Anwar MI. Vitamin D Deficiency in Alopecia Areata. J Coll Physicians Surg Pakistan. 2017;27(4):200-2.

28. Erpolat S, Sarifakioglu E, Ayyildiz A. 25-hydroxyvitamin D status in patients with alopecia areata. Adv Dermatology Allergol. 2017;3(October 2010):248-52. doi:10.5114/ada.2017.67847.

29. Unal M, Gonulalan G. Serum vitamin D level is related to disease severity in pediatric alopecia areata. J Cosmet Dermatol. 2018;17(1):101-4. doi:10.1111/jocd.12352.

30. El-mongy NN, El-nabarawy E, Hassaan SA, Younis ER, Shaker O. Serum 25-hydroxy vitamin D3 level in Egyptian patients with alopecia areata. 2013:37-41. doi:10.1097/01.EWX.0000419612.74665.2b.

31. Bakry O, El Farargy S, El Shafiee M, Soliman A. Serum Vitamin D in patients with alopecia areata. Indian Dermatol Online J. 2016;7(5):371. doi:10.4103/2229-5178.190504.

32. Enayat M. Attwa, Abdallah H. Kandi WE and AMS. Assessment of Vitamin D Level in Patients of Alopecia Areata. J Clin Investig Dermatology. 2016;4(2):4. doi:10.13188/2373-1044.1000030.

33. Darwish NMM, Marzok HF, Gaballah MAM, Abdellatif HE. Serum level of vitamin D in patients with alopecia areata. Egypt J Basic Appl Sci. 2017;4(1):9-14. doi:10.1016/j.ejbas.2016.12.001.

34. Mahamid M, Abu-Elhija O, Samamra M, Mahamid A, Nseir W. Association between vitamin D levels and alopecia areata. Isr Med Assoc J. 2014;16(6):367-70. http://www.ncbi.nlm.nih.gov/ pubmed/25058999.
35. Ovidio R, Vessio M, Domenico F. Reduced level of 25-hydroxyvitamin $\mathrm{D}$ in chronic / relapsing Alopecia Areata. Dermatoendocrinology. 2013;5(2):271-3.

36. Aksu Cerman A, Sarikaya Solak S, Kivanc Altunay I. Vitamin D deficiency in alopecia areata. Br J Dermatol. 2014;170(6):1299-304. doi:10.1111/bjd.12980.

37. Unal M, Gonulalan G. Serum vitamin D level is related to disease severity in pediatric alopecia areata. J Cosmet Dermatol. 2017;(April):3-6. doi:10.1111/jocd.12352.

38. Attwa E, Kandil A, Elbalaat W, Samy A. Assessment of Vitamin D Level in Patients of Alopecia Areata. J Clin Investig Dermatology. 2016;4(2):4.

39. Kim G, Bae J-H. Vitamin D and atopic dermatitis: A systematic review and meta-analysis. Nutrition. 2016;32(9):1-8. doi:10.1016/j. nut.2016.01.023.

40. Boonpiyathad T, Pradubpongsa P, Sangasapaviriya A. Vitamin d supplements improve urticaria symptoms and quality of life in chronic spontaneous urticaria patients: a prospective case-control study. Dermatoendocrinol. 2014;:e29727. doi:10.4161/derm.29727.

41. Topal IO, Kocaturk Goncu OE, Gungor S, Durmuscan M, Sucu V, Yildırmak S. Does replacement of vitamin D reduce the symptom scores and improve quality of life in patients with chronic urticaria? J Dermatolog Treat. 2015;6634:1-19. doi:10.3109/09546634.2015.1079 297.

42. Rorie A, Goldner WS, Lyden E, Poole J a. Beneficial role for supplemental vitamin D3 treatment in chronic urticaria: a randomized study. Aaai. 2014;112:1-7. doi:10.1016/j.anai.2014.01.010.

43. Finamor DC, Sinigaglia-Coimbra R, Neves LCM, et al. A pilot study assessing the effect of prolonged administration of high daily doses of vitamin $\mathrm{D}$ on the clinical course of vitiligo and psoriasis. Dermatoendocrinol. 2013;5(1):222-34. doi:10.4161/derm.24808.

44. Perez, A., Raab, R., Chen, TC., Turner, A., Holick M. Safety and efficacy of oral calcitriol (1,25-dihdroxyvitamin D3) for the treatment of psoriasis. Br J Derm. 1996;134:1070-8. 